\title{
A Ghostly Closure? The Strange History of Brinkley Female College, Nineteenth-Century Spiritualism, and the Terminal Effects of Sensationalist Journalism
}

\author{
R. Eric Platt ${ }^{*}$ \& Hannah Holliman Parris ${ }^{a}$
}

* Corresponding author Email: replatt@memphis.edu a. Department of Leadership, University of Memphis, TN, United States.

\section{Article Info}

Received: January 9, 2022

Revised: February 5, 2022

Accepted: February 11, 2022

\subsection{3/jcsr.2022.6}

\section{How to cite}

Platt, R. E., \& Parris, H. H. (2022). A Ghostly Closure? The Strange History of Brinkley Female College, Nineteenth-Century Spiritualism, and the Terminal Effects of Sensationalist Journalism. Journal of Curriculum Studies Research, 4(1), 58-75 https://doi.org/10.46303/icsr.2022.6

\section{Copyright license}

This is an Open Access article distributed under the terms of the Creative Commons Attribution 4.0 International license.

https://creativecommons.org/licenses/by/4.0/

\begin{abstract}
In 1871, Brinkley Female College in Memphis, Tennessee, closed due to a ghost story, regional interest in Spiritualism, and sensationalist journalism that harmed the short-lived academy. Spiritualism-a religio-spiritual movement punctuated by medium-guided communications between the living and deceased-was wellfollowed, though often contested during the nineteenth century. Spiritualism grew in popularity in the American South due to mass deaths resulting from epidemics and the American Civil War. At the same time, sensationalist print media was widespread, and newspaper firms profited from unchecked accounts of Spiritualist seances and supernatural encounters. In the midst of this, higher education had expanded across the state of Tennessee. In the early years of Memphis-based women's higher education, newspapers stoked interest in the paranormal by publishing unverified events attributed to a local women's college. Sensationalist, penny-dreadful newspaper accounts influenced public perceptions, caused enrollment decline at Brinkley Female College, and resulted in institutional closure. As such, this case study recounts an unusual catalytic moment within the context of heightened Spiritualistic belief and uncouth journalistic practices. Ultimately, this study seeks to detail the influence of regional religious practices and sensational journalism on institutional termination.
\end{abstract}

\section{KEYWORDS}

Brinkley Female College; spiritualism; Southern women's higher education; nineteenth-century sensationalist journalism; college closure; higher education history. 


\section{INTRODUCTION}

On March 5, 1871, the Daily Memphis Avalanche printed and circulated the strange tale of the "Brinkley Female College Ghost Story." Emphasized by titillating language that set an eerie tone, the newspaper account opened with the following question: "Do disembodied spirits haunt the scenes where they frequented while in the flesh? It is a mixed question; the theory that they do having as firm believers as it has disbelievers." The article continued, "We know of no one who has seen an article of that description [ghosts] - at least we never knew of one till [sic] now." The column continued with a description of bizarre events, "strange and startling incidents incidents so strange they will scarcely be credited by the most credulous." The tale detailed students haunted by a ghost in a pale pink dress. It also described the academic building as decrepit and "decidedly unattractive" college building-"once a palatial residence . . .[that] ruined its builder. The article surmised that the Greek Revival structure "has borne the reputation of being haunted for some time. . . If there be GHOSTS OF THE DEPARTED [emphasis in original] on earth, it is just such as place as such things would select for a trysting or abiding place" ("An Exciting Story" 1871).

Reprinted in newspapers as far-flung as Manitowoc, Wisconsin ("An Exciting Story" 1871); Philadelphia, Pennsylvania ("A Ghost at College" 1871); and New Orleans, Louisiana ("The Latest Ghost Story" 1871"), the article extolled that "South Memphis is in a furore [sic] of excitement over occurrences of a supernatural nature recently made public which concern the BRINKLEY FEMALE COLLEGE [emphasis in original] and its inmates" ("The Latest Ghost Story" 1871). In a list of current events across Tennessee, the following was written that same year: "Brinkley Female College, in South Memphis is haunted-an apparition has been seen several times" ("State Items" 1871). Uncouth journalists reprinted the narrative with penny-dreadful details. Set amidst the backdrop of Spiritualism - a religio-spiritual movement punctuated by medium-guided communications between the living and deceased-the story turned a profit for newspaper firms but heaped infamy on the academy. The tale not only included a female college student plagued by a ghost, but it also recounted related seance activities, ominous spiritual messages, and a mystery surrounding buried money and ownership of the college property. Though officials eventually revealed that the ghost story was a hoax, its consequences were palpable and resulted in the termination of one of Tennessee's earliest women's academies.

The case of Brinkley Female College (particularly its closure) permits an exciting opportunity to explore media influence on Southern Reconstruction-era academic survivalparticularly in light of a significant faith movement and regional interest in the supernatural. As such, ghost stories pervaded newspapers and captivated readers (Sachsman 2017). In the modern era, authors have published accounts of haunted colleges in both public and scholarly venues relying either on popular retellings or unverified documentation (Tucker 2007, Ogden 2014). However, no academic study has examined the academic organizational repercussions of such events. Using newspaper accounts (whether promoting or deriding the college ghost 
story) to detail this unique case of higher education closure, this study seeks to explore the influence of period Spiritualism and sensational journalism on institutional termination. To that end, this study also provides an overview of early Tennessee women's higher education, nineteenth-century Spiritualist beliefs, and the influence of sensationalist print media in order to paint a fuller picture of related social circumstances.

\section{Establishing Women's Higher Education in Tennessee}

While women's colleges such as Mount Holyoke (1837), Radcliffe (1879), and Bryn Mawr (1885) opened in the North, similar institutions opened in the American South. Such Southern women's academies included Wesleyan Female College (1837), in Macon, Georgia, Columbia Female College (1854) (present-day Columbia College) in South Carolina; Sophie Newcomb College (1886) in New Orleans; and the Mississippi State College for Women (1884) (renamed Mississippi University for Women in 1974) in Columbus (Solomon 1985, Bradshaw and Bennett 2021). Similarly, women's colleges opened in nineteenth-century Tennessee in towns that boarded the western expansion of the state. For example, roughly four years after the Southwest Territory officially became the State of Tennessee (1796), Blount College (founded 1794 in Knoxville) enrolled its first female students alongside male pupils.

In 1807, Blount College was renamed East Tennessee College and charted as a statesupported institution. Owing to enrollment difficulties, the academy closed in 1809 and remained shuttered until its 1820 reopening as an all-male institution. In 1869, the college's title changed to the University of Tennessee (Montgomery, Folmsbee, and Greene 1984). Responding to Knoxville's lack of women's higher education, Knoxville Female Academy opened in 1827 (renamed East Tennessee Female Institute in 1846, closed 1911) (Brown 2021, Luttrell 1945). As pioneers settled the state westwardly, female colleges opened in newly established cities on the fringes of the Southwest Territory. Examples include Fisk Female College (18051843), Cumberland Female College (1850-1892), and Mary Sharpe College (1851-1896) (Brown 2021).

These early Tennessee women's academies reflected temporal norms of female instruction-domesticity, classic literature, languages, music, and art (Farnham 1995). Though many closed, the establishment of female higher education continued to follow state expansion. In 1819, Andrew Jackson, John Overton, and James Winchester founded the City of Memphis on the banks of the Mississippi River. However, the urban port city did not play host to a women's college until 1858. That year, the Methodist-Episcopal Church helped organize the State Female College. First administered by Rev. Stephen G. Starke and later Rev. Samuel Watson, this academy closed during the Civil War but reopened afterward. However, because of period financial difficulties, annual epidemics, and poor church support, the college maintained low enrollments and closed in 1880 (Young 1916). Ten years after the State Female College's establishment, Brinkley Female College also opened in Memphis (1868) to provide additional educational opportunities in the growing Southern metropolis. 


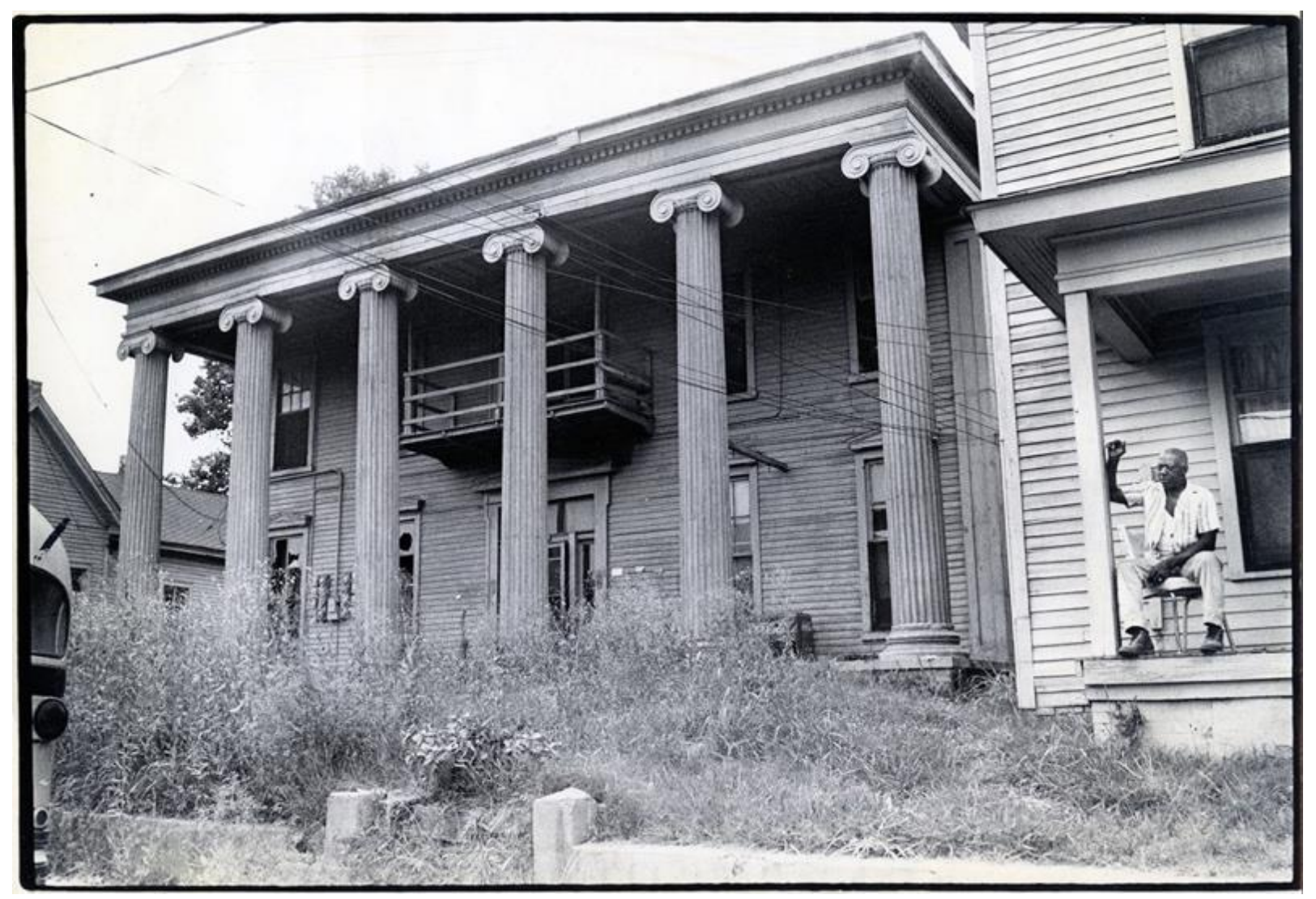

Image 1. "[Abandoned] Brinkley Female College building," c. 1972. Image courtesy of the University of Memphis Libraries, Special Collections Department, Commercial Appeal Newspaper Morgue, Memphis, Tennessee.

Memphis railroad baron Robert Campbell Brinkley founded this new. Brinkley was born in North Carolina but later relocated to Jackson, Tennessee. After passing the bar in 1839, he moved to West Tennessee as a legal representative for the Planters Bank of Nashville. In Memphis, Brinkley married into the wealthy Overton family and took charge of their finances and landholdings. After the 1845 death of his wife Anne, he gave up law to become a real estate broker and city developer. Using inherited money, Brinkley launched a new Memphis-based railroad company, built several downtown buildings, and opened the Peabody Hotel in 1869 (named for his longtime friend and educational philanthropist George Peabody). Perhaps owing to Peabody's influence and the creation of the Peabody Education Fund in 1867, Brinkley decided to engage in an academic endeavor of his own (Schaefer 2012, Parker 1995). While purchasing property to expand his railroad enterprise, Brinkley acquired the home of Winston Jones Davie in 1866. While building his now-famous Memphis hotel, Brinkley remodeled the Davie building and repurposed it as a new women's college. Under the direction of Rev. J. D. Meredith as president, the academy enrolled its first pupils mere months before the hotel mentioned above opened its doors ("Brinkley Female College" 1869).

Despite being founded by a wealthy rail and real-estate magnate, the college gleaned its operational budget primarily from tuition dollars and course fees. It appears that the academy opened with little fanfare but soon had a relatively healthy attendance of young women 
heralding from Memphis and surrounding communities. Soon after its establishment, newspapers regularly published solicitations for the college. These advertisements described instructor acumen, credentials of the acting president, fee structure, and listed courses: reading, arithmetic, philosophy, languages including Greek, French, Spanish, German, and Italian, and music (harp, piano, instrumental, vocal performance) ("Brinkley Female College" 1869). In 1869, the Tennessee Legislature issued a charter for the institution. It also recognized the college's governing board, which consisted of several notable Memphis residents: R. C. Brinkley (founder), J. D. Meredith (college president), Archibald Wright (Tennessee Supreme Court justice), F. A. Ramsey (Confederate doctor and Memphis surgeon), J. J. Williams (Tennessee senator), J. R. Graves (Baptist preacher), George Gautt (Confederate colonel and local lawyer), and R. F. Looney (Confederate colonel, lawyer, and businessman) ("Acts of the State of Tennessee" 1870, Marks 1893, Cunningham 2015, "Election Returns" 1876, Patterson 2012, "Court-House Notes" 1879, Speer repr. 2003).

After two years of steady growth, Brinkley Female College possessed a charter, a governing board comprised of active Memphians, and enrolled approximately fifty students in 1870. The institution was well-liked by the community and was yet another of Robert Brinkley's successful enterprises. That year, advertisements described the institution as "the largest college in Memphis, and the cheapest in the world" ("Brinkley Female College South End of Desoto" 1870). Though Brinkley Female College possessed a governing structure and curricula similar to its Southern academic peers, it closed after only three years of operation. Unlike other shuttered nineteenth-century colleges and universities, Brinkley Female College closed from a regional interest in Spiritualism and attempts by newspaper firms to turn a profit by exploiting unverified reports of Spiritualist activities.

\section{The Rise of Spiritualism}

Spiritualism was an offshoot of the eighteenth-century German mesmerism movement, which held that living creatures possessed a natural, invisible internal force, or spirit, that continued to exist after death. Not only could this spirit manifest itself to the living, but it could also interact with the physical realm. Emanual Swedenborg, the Swedish scientist and theologian, bolstered Spiritualism with his published revelations concerning the rebirth of human spirits. Spiritualist leaders relied on Swedenborg's publications-notably his 1757 book, De Nova Hierosolyma et ejus Doctrina Coelesti (Concerning the New Jerusalem and its Heavenly Doctrine). Spiritualists used such texts to reinforce the idea that the invisible spirit referenced in mesmerism not only existed beyond the mortal plane but could also communicate with the living (Franklin 2012, Oberter 2012). In 1848, the Spiritualist movement gained intense notoriety. In Hydesville, New York, Kate and Margaret Fox reported communicating with the deceased through spirit rappings and knockings. Both sisters became well-known mediums. Their experiences, though later discredited, encouraged others to practice Spiritualism (Weisburg 2005). 
Meanwhile, in Europe, Spiritualism intensified. In 1857, French educator and author Hippolyte Léon Denizard Rivail published Le Livre des Esprits (The Spirits' Book). Writing under the pseudonym Allan Kardec, Rivail extolled the tenets of Spiritualism: God is the supreme intelligence; God is eternal; spirits exist; spirits are "destined to attain perfection by passing through the different degrees of the spirit-hierarchy"; people retain their individuality after death; spirits are privy to memories from past lives; spirits can influence the physical world; and that there are good and evil spirits that either try to help the living or seek the downfall of humankind. Moreover, most spirits maintain the supreme maxim of "do good to all, and wrong to no one." (Kardec repr. 1893, 15-18).

Primarily imparted by print media, Spiritualism also spread through related publications, including the Banner of Light, the Spiritual Clarion, and the Spiritualist Register, to name a few. In America, as in Europe, media enhanced the faith and increased Spiritualism's Earthly ranks (Noakes 2012, Nartonis 2010). Well-known late-nineteenth-century European and American followers included Queen Victoria of England, Mary Todd Lincoln, Thomas Edison, and Sir Arthur Conan Doyle, the mind behind the renowned fictional detective and skeptic Sherlock Holmes (Brennan 2013, Yuko 2021). Reflecting on the history of Spiritualism and its global expansion, the novelist Doyle wrote, "[M]any of us regard [Spiritualism] as the most important [religious movement] in the history of the world since the Christ episode" $(1926$, vii). By 1870, over four million US citizens believed in Spiritualism (Ellis 1870).

Spiritualism did more than shape citizens' concepts of death and the afterlife. As ghosts appeared and spoke through mediums, regional and national political movements, racial mores, and gender dynamics were reinforced or, in some cases, derided by the departed as inequalitarian. Social inequality, per some spirits, was in opposition to the conventions and hierarchies of the afterlife-i.e., all were equal after death. Each spirit worked to perfect its soul and ascend the hierarchy of afterlife perfection (Cox 2017, Clark 2016). In the United States, followers regarded Spiritualism as a religion with a formal belief structure and science that could provide proof of the afterlife (Ferguson 2012). Confirmation of the supernatural manifested through seances was enough to heighten curiosity, but media reinforced the movement throughout the country. In New York and Boston, Spiritualism became a regular craze with seance parties hosted by affluent citizens. Summoned spirits announced their presence by rapping on tables, moving objects, and writing on tablets (Coleman 1861).

Spiritualism also took hold in Southern cities like New Orleans and Cassadaga, Florida. Spiritualists in New Orleans formed Le Cercle Harmonique (The Harmonic Circle) in the early 1850s to commune with the dead. In Memphis, Protestant preachers inculcated portions of Spiritualism into their denominational practices to showcase the afterlife rewards for lives welllived (Clark 2016, Davie 1999). Though chastised by his bishop, Methodist minister, and second president of the Memphis-based State Female College, Samuel Watson, was a follower of Spiritualism and published his experiences with and investigations into the metaphysical. Watson supported his argument for the existence of spirits by quoting from First Peter, chapter 
three, verses eighteen through nineteen. Couched in his Spiritualistic interpretation, Watson explained, "Christ . . . being put to death in the flesh . . . preached unto the spirits in prison, which sometime were disobedient.' 'Prison' here ... should be translated 'spirit world'" (1872, 110).

Reconstruction-era Memphians, like many Southerners, suffered from the deleterious effects of the Civil War, the realities of post-emancipation economics, and yearly episodes of yellow fever. As a result, locals were all too familiar with death, and Spiritualism offered connection with lost loved ones (Land 2020). Though criticized by nineteenth- and earlytwentieth-century Christian religious leaders, Spiritualism maintained a significant US presence until its decline in the 1920s owing to debunkers and splintered Spiritualist sub-groups (Hess 1993).

\section{Sensationalist Reporting and the Spiritualist Movement}

As Spiritualism gained notoriety, many Memphians followed the movement like several of their Southern counterparts. Newspaper reporters steadily labeled and described Spiritualist content with dramatic language, which increased sales. Some editors understood the financial profit of sensationalist journalism, which intended to entertain, arouse, and amuse-not necessarily inform (Francke 1985). As historian George Juergens explains, "Sensational newspapers expanded the meaning of the human-interest story to report what had hitherto been regarded as private, the gossip and scandals about individuals, and discovered a rich source of news in crime and everyday tragedy" (1966, vii-ix). The excitement of seances, ghostly apparitions, and medium possessions played well into sensationalist journalism. Tying an exciting ghost story to a local women's college was fodder for Memphis newspapers. Other reporters and newspaper editors chided their peers for publishing otherworldly accounts filled with grim descriptions of unverified events.

Newspaper editors quickly learned that exciting, sensationalized stores boosted sales, which increased profit. As a result, newspapers often published sensationalist reviews of seances and Spiritualist gatherings without verifying facts (Buescher 2004). In the latter half of the 1800s, newspapers in major metropolitan areas competed for top sales. Sensationalist journalism added an unethical edge to beat media competitors by attracting the attention of uneducated citizens. As immigrants poured into America, newspapers became a source for literacy learning. Various newspapers took advantage of low education levels and published salacious accounts with jargoned headlines and exciting cartoon sketches (Juergens 1966). David W. Bulla and David B. Sachsman further detail, "Newspaper coverage in the nineteenth century [was] directly related to changes in the social and cultural fabric of the nation. While the early American press tended to focus on politics, business, and religion, by the midnineteenth century, the urban press began to put more and more emphasis on local news, including crime and corruption, filth and freaks, and gore and guts. One aspect of 
sensationalized coverage was fabrication" (2013, xxii). To that end, local interest pieces that used period fascination with Spiritualism and ghost stories enhanced newspaper sales.

Similarly, Southern print media often profited from sensationalized retellings of ghost stories and dimly-lit seances. Reporters attended theaters and opera houses that hosted live seances and recounted the events with dramatic details in the days that followed. All the while, Spiritualist theatre tickets sold en masse (Natale 2011). Not all benefited from Spiritualism's media fame, however. Indeed, charlatans exploited the beliefs of Spiritualist followers, advertised themselves as mediums, and profited from the grieving, the curious, and the zealous. Despite the rise of Spiritualism as a recognized religion following the Second Great Awakening (1795-1835), newspapers published uncouth reports with the same alacrity as those deemed genuine. As a result, Spiritualist investigators traveled the country exposing fraudulent mediums. Later in life, Erik Weisz (also known as Harry Houdini) spent considerable time attending seances to reveal "tricks" employed by unscrupulous individuals (Guzzo 2019).

Researchers have carefully examined the impact of adverse media reporting on religious practices and associated educational institutions. For example, in the American South, Catholic churches and colleges were often targets for anti-Catholic sentiment in newspapers and other forms of print media. Similarly, the Society of Jesus, otherwise known as the Jesuits, experienced intense negative media portrayals resulting from regional anti-Catholic/anti-Jesuit sentiment (Platt 2014, Stern 2012). However, scholars have yet to examine the intertwined influence of Spiritualism and sensationalist journalism on organizational survival. Though print media often contributed to inaccurate social perceptions, nineteenth-century newspapers did not always print sensationalism. In addition to providing regional news, election results, and obituaries, they also solicited businesses, services, and printed advertisements for colleges, schools, and academies. Even so, sensationalist journalism was ever-present in Southern media and often enhanced political mudslinging, harmed businesses, influenced public opinion on legal cases and immigration issues, and bolstered public interest in ghosts (Bulla and Sachsman 2013).

\section{The College Ghost: Fiction and Truth}

While Memphis newspapers reported a crumbling Brinkley Female College building with frightened female students, newspaper accounts failed to describe the structure and its origins accurately. The original building owner, Winston Davie, graduated from Yale College in 1845. Before residing in Memphis, he owned and managed a Kentucky cotton and tobacco plantation and served in the Kentucky legislature. After losing a congressional election in 1853, Davie moved to Memphis and became a banker. After that, he built an imposing Greek-revival house in 1861 for his family, consisting of his wife Sarah Ann Phillips and two sons. In 1859, Sarah passed away. Davie remarried in 1861 to Addie E. Kalfus of Louisville, Kentucky. Together they had one son. With the start of the Civil War, Davie joined the Confederate Army as a colonel ("Winston Jones Davie" 1887, McAfee 1886). However, before doing so, he acquired a $\$ 30,000.00$ mortgage to purchase stock in Brinkley's growing railroad firm. Though Davie 
entered the war a wealthy man, he exited in financial ruin. Davie lost his fortune in the wake of Confederate currency devaluation and sold his home to Brinkley to help settle debts (Hulan and Giebner 1972). Davie moved his family back to Kentucky and, in 1869, declared bankruptcy as he could not finalize his Memphis liabilities. Davie served as Kentucky's agricultural commissioner from 1876 to 1879 and later manufactured chemical fertilizers in Louisville. Davie was often ill in his old age and lived with his son until he passed away in 1887 ("Winston Jones Davie" 1887).

Davie was described altogether differently in the Brinkley Female College ghost story. Per the phantasmagoric tale, Davie squandered his money constructing the Memphis mansion. When construction finished, Davie's daughter Elizabeth died. According to the story, Elizabeth was referred to as "Lizzie" by family and friends. Having lost his daughter and fortune, Davie went mad before the Civil War and died. Genealogical records, however, do not indicate that Davie had a daughter by either spouse or suffered any mental illness ("Winston Jones Davie" 1887, "Here and There" 1887). Similarly, financial records do not support Davie losing his money before or at the onset of the war. Though false, descriptions of Davie's supposed insanity, the death of Lizzie, and descriptions of the building's gloomy, ghost-inhabited façade, did much to "set the stage" for newspaper readers ("An Exciting Story" 1871).

After the college opened, Memphis resident Clara Robertson enrolled in the academy. According to newspapers, in the spring of 1870 , Clara was practicing piano in an upper room of the college building when she witnessed the apparition of a girl in a moldy pink dress. Clara, unnerved by the specter, fled the room and confided in her college peers but was chided as delusional. Likewise, the academy's faculty dismissed Clara's bizarre claims. Nevertheless, Clara and other students witnessed the ghost in the academy's music room a few days later. Frightened, the young women fled, reported this second incident, but, once again, failed to garner support. Clara, described in news reports as having a nervous but kind temperament, "has never been in any way connected with things supernatural or to have put trust in spiritualists. Her [recent] experience[s] ..., however, are more wonderful and startling than the mysteries of Udolpho or the horrors of Kenilworth Castle" ("An Exciting Story" 1871, np). For several days, Clara recovered at home. After she arrived back at the college, the ghost appeared for a third time and, "pointing a thinly ghastly looking finger," directed the student to recover valuables that belonged to Lizzie's supposed father, Colonel Davie. The ghost, now referred to as "Pink Lizzie," told Clara that the college building, formerly Lizzie's home, was acquired by Brinkley through nefarious means. Lizzie instructed Clara that the building's original deed, jewelry, and several gold coins were buried in a jar under a stump behind the building ("An Exciting Story" 1871).

Lizzie, it seemed, "would have Miss Clara take possession of [the jar and its contents], and use to her advantage." The newspaper extolled that "dismay now prevailed throughout the institution" and that none of the college's students doubted the existence of Pink Lizzie. After Clara told her father, Memphis lawyer J. C. Robertson, he met with the college's president, 
Meredith. Both Robertson and Meredith "agreed that the affairs should undergo a rigid investigation as it was doing no good to the reputation of the college, while little Clara was much troubled and disturbed in mind." Meredith and his staff gathered the students in order to interview them. Clara was sent outside during the interrogation, but the Spirit of Lizzie visited the student once again. The ghosts urged Clara to unearth the jar. Lizzie, per Clara, insisted that the college's owner held the property illegally and that "as her people were all dead . . . she desired Clara to obtain the papers ... [and] claim and retain the property" ("An Exciting Story" $1871, \mathrm{np})$. Once again, errors in the ghost story abounded as members of the Davie family, including Winston Davie, were alive and residing in Kentucky. Though newspapers circulated the ghost story, no documentation showcases a response from the Davie family. Similarly, there is no evidence to suggest that Winston Davie himself was ever aware of the spiritual happenstances at his former Memphis home.

The story continued to spread, and, as a result, enrollment declined. Per the story, "several young ladies went home frightened out of their wits, and several others were affected with illness." Clara told her father, "she WOULD RATHER DIE [emphasis in original] than go there [to the college] again." Prior to serving as a Memphis attorney, Robertson plied his legal trade on the East Coast and made the acquaintance of a Spiritualist medium known only as Mrs. Nourse. Robertson, now in west Tennessee, contacted Nourse and brought her to Memphis to support the investigation. Nourse engaged Robertson, his daughter Clara, and other Memphis citizens in a seance where the spirit of Pink Lizzie possessed Clara ("An Exciting Story" 1871, np). According to reporters, the seance commenced as follows:

All seated themselves about the table, placing their hands on its surface. Mr. Robertson, always skeptical and doubting the truth of the story, watched with the eye of a hawk to detect fraud of collusion. His doubting mind, with that of several others, who had during their natural existence ridiculed ghosts and spirits, was soon awe and wonder struck at the strange actions that followed. The little girl [Clara] . . swooned, falling back into her chair apparently lifeless, and certainly insensible. Her eyes stood wide open, fixed on vacancy. Her hands began to move. Soon they moved faster, and in a short time their violent action frightened the parent, who caught hold of his child's arm to prevent doing herself harm. Those present (some dozen or more) were amazed at the child's behavior and appearance. In due time they became tranquil, as did also the hand of Miss Clara, though not ... until all the skin had been barked from the knuckles . . . ("An Exciting Story" 1871, np)

Nourse then placed a pencil in Clara's palm, and Lizzie, through Clara, recounted the building's fraudulent ownership as well as the buried valuables. Following the seance, Robertson hired men to excavate behind the college. The dig attracted widespread interest, and the "Brinkley College Ghost Story" was updated and reprinted ("Uproar in a Tennessee Educational Institute" 1871, "Alas, Poor Ghost" 1871). Initially considered a "supposed" ghost sighting, the tale now included an interesting twist-- buried treasure. This new information, coupled with the 
continued reports of spiritualists and mediums, only intensified the story, and enrollment dwindled.

\section{Consequences and Closure}

Out of concern, parents withdrew their daughters. Understandably, Lizzie's moldering, pale ghost did not represent the regionally accepted peaceful image of the afterlife, nor did the excavation endear the college to the public. Still, the search for buried treasure continued. As the college struggled, Meredith printed advertisements promoting the institution. The college president denounced the ghost story as false in hopes of swaying public opinion. In addition, he emphasized that the college was a quality institution. Concerning Clara, Meredith stated, "Miss Robertson ... did see sights here, and she can see them anywhere; for she takes her ghosts with her, and I leave medical men to dispose of her case scientifically." ("Dear Avalanche" 1871). Not long after that, Robertson produced a dirty glass jar supposedly uncovered at the dig site. Clara's father stated that he could see paper documents and metal objects inside the jar. However, as before, Clara was visited by Pink Lizzie, who informed the student not to open the jar for sixty days - The spirit did not give reasons for the delay. Robertson then hid the jar in a "safe location" (his latrine outhouse) and advertised the jar's opening as a spectacular event to be held at the Greenlaw Opera House (Robertson 1871).

Initially, Robertson advertised that he would donate half of the ticket revenue to the Episcopal Church. The bishop disapproved of the Spiritualist-related unveiling and declined the money. He then admonished Robertson for being a follower of Spiritualism. Brinkley Female College's headmaster opposed the ghost story and decried Robertson as a fraud. After Robertson published his philanthropic motivations for opening the jar at a paid event, unidentified assailants attacked him at home and stole the glass container. As a result, theatre managers canceled the jar opening spectacle, and interest in Spiritualist-related events began to wane. To stoke interest and raise funds, Robertson compiled newspaper accounts of the ghost story, interviews with his daughter, and other persons involved with the recent seances. He then his account as a booklet titled The Brinkley Female College Ghost Story, the Finding of the Mysterious Jar, its Opening and Contents: A Thrilling Narrative, Based upon Facts. The text recounted the story, included the original news report, and contained interview transcriptions, as well as claims by president Meredith and other students that no one had seen a spirit on the property. Rebuking Meredith, Robertson added a notation to the educator's comments. The Memphis lawyer stated that Meredith's fraud claims were made "before the finding of the glass jar," perhaps to showcase that the college president spoke too soon. The booklet initially sold for five cents but later sold for thirty (Robertson 1871).

Though Robertson's account may have generated additional revenue for the lawyer, it further compounded difficulties at Brinkley Female College. Meredith faced growing academic competition while defending the college against the ghost story's negative impact. Advertisements listed the still extant State Female College alongside institutions such as the 
newly opened Memphis Female College and the rural LaGrange Female College. During this same time, regional private high schools opened, which may have attracted younger wards from college preparatory divisions ("State Female College" 1870, "Memphis Female College" 1870, "The Fall Session of LaGrange Female College" 1869). After the college's closure in 1871, Meredith tried to revive the institution, but the Brinkley Female College name was too well associated with the notorious ghost story. The following year, Meredith petitioned city officials to forgive property taxes on the failed Brinkley Female College ("Petitions" 1872). Afterward, Meredith opened a new academy under his name, "Meredith Female College," but its success was short-lived ("Meredith Female College" 1871). It was recorded in 1873 that Meredith left Memphis for the nearby rural community of Somerville, Tennessee, and served as president for the Somerville Female Institute (Meredith and Venable 1873).

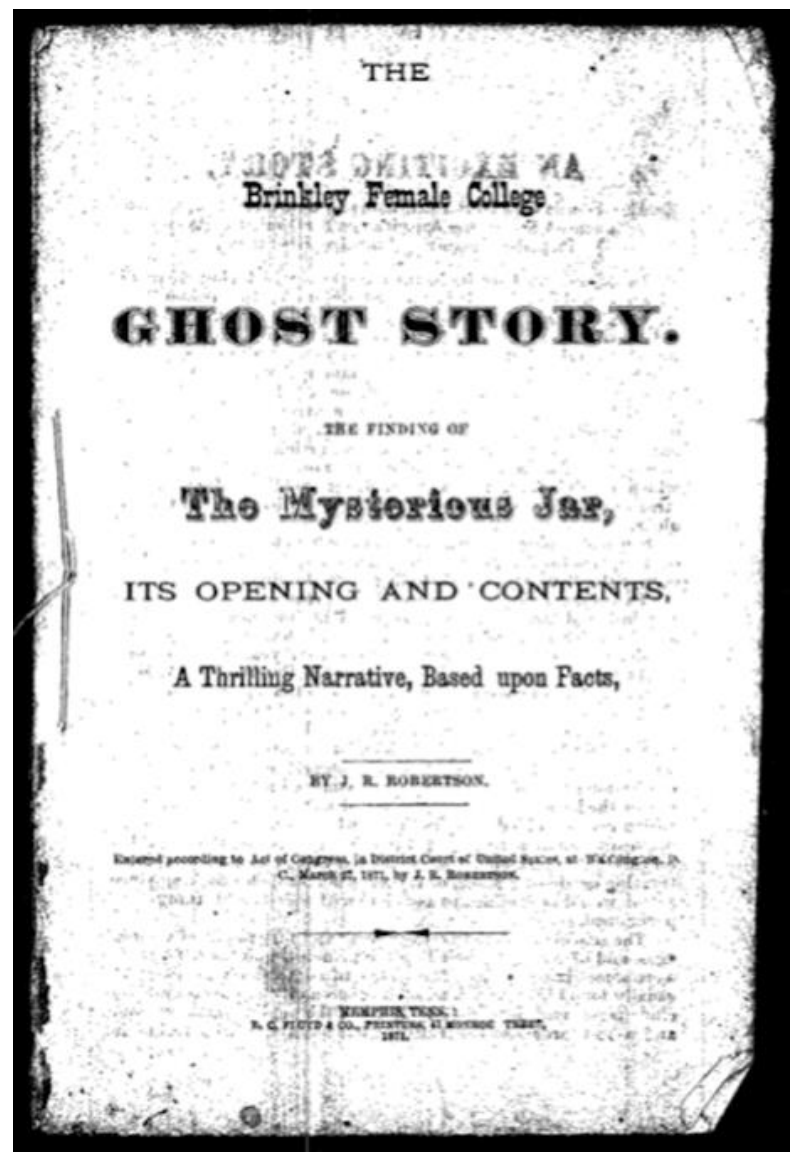

Image 2. Robertson, J. C. 1871. The Brinkley Female College Ghost Story, the Finding of the Mysterious Jar, its Opening and Contents: A Thrilling Narrative, Based upon Facts. Image courtesy of the Indiana University Archives and Special Collections, Wright American Fiction, Bloomington, Indiana.

Despite the relatively short existence of Brinkley Female College, Memphis played host to other forms of late-nineteenth-century higher education such as the Memphis Medical College (1846), Lemoyne College (1862), Nelson's Business College (1887), Christian Brothers College (1871) - to name a few. As mentioned, other forms of female higher education opened in Memphis. However, most of these gender-segregated institutions closed or merged with 
other colleges prior to or during the twentieth century. In 1922, the female-serving St. Agnes College opened (renamed Siena College 1930, closed 1972). Lasting regional women's higher education expanded with the 1912 founding of West Tennessee State Normal School (presentday University of Memphis) and the mid-twentieth-century admittance of women to other institutions such as Christian Brothers University and Rhodes College (Brown 2021, Sherman 2010, "Our History" 2022, Boone and Rathbone 2017).

Though Meredith had given up on salvaging Brinkley Female College, pressure mounted for authorities to investigate the ghost story further. Officials questioned Clara and her father, and although Clara maintained her story, Robertson confessed that he fabricated the tale. Not long after, Robertson and his family relocated to Arkansas. The Memphis Daily Appeal promulgated the confession, further discredited the ghost story, and criticized the editors of the Daily Avalanche for publishing and reselling reprints of the ghost story ("The Ghost" 1871, "The Great Propensity of Mankind to be Gulled, Duped and Humbugged" 1871). Indeed, when the Avalanche's editor backed local political candidates in opposition to those supported by rival newspapers, articles ran that opined, "Is some Brinkley College ghost still haunting the dreams of the Avalanche editor?" ("Why the Hostility to Colonel Haynes?" 1872). Following the revelation that the ghost story was a hoax, newspapers slowly stopped reporting Spiritualist activities. In contrast, others printed exposés of fraudulent mediums as well as columns on the "falseness" of Spiritualism ("Ledger Lines" 1876, "Letters from the People" 1877, "To the Citizens of Memphis" 1881).

\section{Conclusion}

Although Spiritualism declined in the early twentieth century, the tale of Pink Lizzie and the detrimental effects of sensationalist reporting left their mark not only on the college and its affiliates but also on Clara Robertson. Months after the college's closure, Clara began performing on stage as a Spiritualist medium, first with her father narrating stage performances and later on her own or with other Spiritualist colleagues. Clara married a local merchant, John Zent, and her social circle expanded. Her new acquaintances were amazed by her Spiritualist talents and publicly recognized that Clara never lost her abilities as a medium. Clara performed until the age of 25 , when she passed away from consumption in Wittsburg, Arkansas. Zent had his wife buried in the Memphis Elmwood Cemetery. She lies not far from the grave of college founder Robert Brinkley ("Clara Robertson Zent" 2015, "Dr. Watson's Reply to 'Gayoso'" 1877, "The Spiritualist" 1871).

Despite the egress of Meredith, Robertson, and Clara, the results of the Brinkley Female College ghost story were long-lasting. Although he owned the college, it appears that Robert Brinkley never publicly commented on the ghost story, nor was he mentioned as the college began to flag. Similarly, no uncovered documentation describes any response from the college's board members other than president Meredith. When Brinkley died in 1878, his third son, William Junius Brinkley, inherited the failed college building. William sold the building to Jennie 
Breen of Memphis in 1898 (Hulan and Giebner 1972). The college property changed hands several times in the early twentieth century. For a time, the building served as lodgings for railroad workers before being demolished in the 1970s. Today, a recycling center stands on the foundations of the short-lived academy (Gill, French, and White 2011). Though the building has gone, the ghost story persists in popular publications such as Haunted Memphis by Laura Cunningham (2009) and Malice in Memphis: Bluff City Mysteries by Carolyn McSparren (2014). The story is also recounted and embellished by Memphis tour guides that cater to the macabre.

Regardless of the ghost story's popularity, this narrative serves as a case example of academic longevity and termination in the face of media sensationalism associated with a religio-spiritual movement that attracted the praise, imagination, and skepticism of scholars, theologians, and the general public. As Darryl L. Peterkin explains, "Institutions of higher learning are not in the least immune from the influence of powerful individuals, momentous social, cultural, and economic forces, or cataclysmic events of any kind" $(2010,17)$. Though scholars may never fully explain the metaphysical "facts" surrounding the college ghost story, enhanced research regarding its influence on academic administration and college closure helps better illustrate the fragility of late-nineteenth-century Southern private higher education. If anything, this case study depicts a catalytic moment that, reinforced by period Spiritualist beliefs and unethical journalistic practices, ultimately caused the closure of an institution of higher education crafted to serve female residents in an important urban sector of the American South.

\section{REFERENCES}

Acts of the State of Tennessee, Passed by the First Session of the Thirty-Sixth General Assembly for the Years 1869-70. 1870. Nashville. Jones, Purvis, \& Co. Printers.

"A Ghost at College." 1871. The Evening [Philadelphia] Telegraph. March 10, 1871.

"Alas, Poor Ghost." 1871. Memphis Public Ledger. March 6, 1871.

"An Exciting Story. Brinkley Female College Haunted and in an Uproar of Terror and

Confusion-A Speculative Apparition on the Ownership of the Property-Singular and Startling Revelation. Daily Memphis Avalanche. March 5, 1871

"An Exciting Story. Brinkley Female College Haunted and in an Uproar of Terror and

Confusion-A Speculative Apparition on the Ownership of the Property-Singular and Startling Revelation." [Reprinted] From the Avalanche, March 5." The Manitowoc Tribune. March 30, 1871.

Boone, Allen \& Jane Cady Rathbone. 2017. Rhodes College: A Sense of Place. Memphis. Rhodes College.

Bradshaw, Lauren Yarnell \& Marcia Bennett. 2021. "'So Firm a Hold': Civil War Resiliency at Wesleyan Female College." In Persistence through Peril: Episodes of College Life and Academic Endurance in the Civil War South, edited by R. Eric Platt \& Holly A. Foster. Jackson. University Press of Mississippi.

Brennan, J. H. 2013. Whisperers: The Secret History of the Spirit World. New York. Overlook Press. 
"Brinkley Female College." 1869. Memphis Daily Appeal. July 26, 1869.

"Brinkley Female College South End of Desoto." 1870. Memphis Daily Appeal. August 8, 1870.

Brown, Ray. 2020. "Index of Colleges and Universities that have Closed, Merged, or Changed their Names." College History Garden. Last modified December 1, 2021.

https://collegehistorygarden.blogspot.com/2014/11/index-of-colleges-anduniversities-that.html.

Buescher, John Benedict. 2004. The Other Side of Salvation: Spiritualism and the NineteenthCentury Religious Experience. Boston. Skinner House Books.

Bulla, David W. \& David B. Sachsman. 2013. "Introduction." In Sensationalism: Murder, Mayhem, Mudslinging, Scandals, and Disasters in $19^{\text {th }}$-Century Reporting, edited by David B. Sachsman. New York. Routledge.

"Clara Robertson Zent." 2015. Find a Grave. February 8, 2015.

https://www.findagrave.com/memorial/142363577/clara-zent

Clark, Emily Suzanne. 2016. A Luminous Brotherhood: Afro-Creole Spiritualism in NineteenthCentury New Orleans. Chapel Hill. University of North Carolina Press.

Coleman, Benjamin. 1861. Spiritualism in America. London. Thomas Scott, Warwick Court.

"Court-House Notes." 1879. Memphis Public Ledger. February 6, 1879.

Cox, Robert S. 2017. Body and Soul: A Sympathetic History of American Spiritualism.

Richmond. University of Virginia Press.

Cunningham, Horace Herndon. 2015. Doctors in Gray: The Confederate Medical Service. Plano.

Golden Springs Publishing.

Cunningham, Laura. 2009. Haunted Memphis. Charleston. The History Press.

"Dear Avalanche." 1871. Daily Memphis Avalanche. March 5, 1871

Doyle, Arthur Conan. 1926. The History of Spiritualism, Vol 1. New York. George H. Doran

Company.

"Dr. Watson's Reply to 'Gayoso.'" 1877. Memphis Daily Appeal. May 19, 1877.

"Election Returns." 1876. Fayetteville Observer. November 9, 1876.

Ellis, John B. 1870. Free Love and its Votaries or American Socialism Unmasked. Being an

Historical and Descriptive Account of the Rise and Progress of the Various Free Love Association in the United States, and of the Effects of Their Vicious Teachings Upon American Society. New York. United States Publishing Company.

Farnham, Christie Anne. 1995. The Education of the Southern Belle: Higher Education and Student Socialization in the Antebellum South. New York. New York University Press. Ferguson, Christine. 2012. "Recent Scholarship on Spiritualism and Science." In The Ashgate Research Companion to Nineteenth-Century Spiritualism and the Occult, edited by Tatiana Kontou \& Sarah Willburn. New York. Routledge.

Francke, Warren. "Sensationalism and the Development of 19th-century Reporting: The Broom Sweeps Sensory Details." Journalism History 12, no. 3-4 (1985): 80-85.

Franklin, J. Jeffrey. 2012. "The Evolution of Occult Spirituality in Victorian England and the 
Representative Case of Edward Bulwer-Lytton." In The Ashgate Research Companion to Nineteenth-Century Spiritualism and the Occult, edited by Tatiana

Kontou \& Sarah Willburn. New York. Routledge.

Gill, Gene, Dave French, \& Maureen White. 2011. "Brinkley Female College . . . and it's

Historic Ghost Story." Historic Memphis. December 9, 2011. https://historicmemphis.com/memphis-historic/brinkley-female-college/brinkley-female-college.html.

Guzzo, Guilherme Brambatti. "Houdini Among the Spirits: A Lesson in Critical Thinking."

Think 18, no. 52 (2019): 47-58.

"Here and There." 1887. Semi-Weekly South Kentuckian. May 17, 1887.

Hulan, Richard H. \& Robert C. Giebner. 1972. "Brinkley Female College (Ghost House): 683

So. Fifth Street, Memphis, Shelby County, Tennessee." Historic American Buildings

Survey. National Park Service, Department of the Interior. Washington, DC. Library of Congress.

http://lcweb2.loc.gov/master/pnp/habshaer/tn/tn0100/tn0127/data/tn0127data.pdf. Juergens, George. 1966. Joseph Pulitzer and the New York Word. Princeton University Press. Kardec, Allan. Repr. 1893. Spiritualist Philosophy, The Spirit's Book: Containing the Principles of Spiritist Doctrine on the Immortality of the Soul: The Nature of Spirits and Their Relations with Men; the Moral Law; the Present Life, the Future Life, and the Destiny of the Human Race. According to the Teachings of Spirits of High Degree, Transmitted Through Mediums, Collected and Set in Order. Translated by Anna Blackwell. Boston. Colby and Rich, Publishers.

Lande, Gregory R. 2017. Spiritualism in the American Civil War. Richmond. University of Virginia Press.

"Ledger Lines," 1876. Memphis Public Ledger. January 28, 1876.

"Letters from the People." 1877. Memphis Daily Appeal. May 19, 1877.

Luttrell, Laura. "One Hundred Years of a Female Academy: The Knoxville Female Academy,

1811-1846; The East Tennessee Female Institute, 1846-1911." East Tennessee Historical Society 17 (1945): 71-83.

Marks, Albert D. "The Supreme Court of Tennessee." The Green Bag 5 (1893): 183.

McAfee, John J. 1886. Kentucky Politicians: Sketches of Representative Corn-Crackers and

Other Miscellany. Louisville. Courier-Journal Job Printing Company.

McSparren, Carolyn. 2014. Malice in Memphis: Bluff City Mysteries. Memphis. Dark Oak Press.

"Memphis Female College." 1870. Memphis Public Ledger. August 30, 1870.

"Meredith Female College." 1871. Memphis Daily Appeal. September 14, 1871.

Meredith, J. D. \& Charles Scott Venable. 1873. Somerville Female Institute: This Large and

Finely Furnished Institute Will be Open to First Monday in September, Under the

Supervision of Rev. J.D. Meredith. Somerville. W. M. Hutton \& Company, Printers.

Montgomery, James Riley, Stanley J. Folmsbee, \& Lee Seifert Greene. 1984. To Foster 
Knowledge: A History of the University of Tennessee, 1794-1970. Knoxville, University of Tennessee Press.

Nartonis, David K. "The Rise of 19th-Century American Spiritualism, 1854-1873." Journal for the Scientific Study of Religion 49, no 2 (2010): 361-373.

Natale, Simone. "The Medium on the Stage: Trance and Performance in Nineteenth-Century Spiritualism." Early Popular Visual Culture 9, no. 3 (2011): 239-255.

Noakes, Richard. 2012. "The Science of Spiritualism in Victorian Britain: Possibilities and

Problems." In The Ashgate Research Companion to Nineteenth-Century Spiritualism and the Occult, edited by Tatiana Kontou \& Sarah Willburn. New York. Routledge.

Oberter, Rachel. 2012. "'The Sublimation of Matter into Spirit': Anna Mary Howitt's Automatic

Drawings." In The Ashgate Research Companion to Nineteenth-Century Spiritualism and the Occult, edited by Tatiana Kontou \& Sarah Willburn. New York. Routledge.

Ogden, Tom. 2014. Haunted Colleges and Universities: Creepy Campuses, Scary Scholars, and Deadly Dorms. Guilford. Globe Pequot Press.

"Our History." 2022. Christian Brothers University.

https://www.cbu.edu/academics/schools/gadomski-school-of-engineering/aboutus/our-history/

Parker, Franklin. 1995. George Peabody: A Biography. Nashville. Vanderbilt University Press. Patterson, James A. 2012. James Robinson Graves: Staking the Boundaries of Baptist Identity. Nashville. B\&H Publishing Group.

Peterkin, Darryl, L. 2010. "'Within these Walls': Reading and Writing Institutional Histories." In The History of US Higher Education: Methods for Understanding the Past, edited by Marybeth Gasman. New York. Routledge.

"Petitions." 1872. Memphis Daily Appeal. February 11, 1872.

Platt, R. Eric. 2014. Sacrifice and Survival: Identity, Mission, and Jesuit Higher Education in the American South. Tuscaloosa. University of Alabama Press.

Robertson, J. R. 1871. The Brinkley Female College Ghost Story, the Finding of the Mysterious Jar, it's Opening and Contents: A Thrilling Narrative, Based upon Facts. Memphis. R. C. Floyd \& Co., Printers.

Sachsman, David B. 2017. After the War: The Press in a Changing America, 1865-1900. New York: Routledge.

Schaefer, Dale. 2012. "Robert Campbell Brinkley." Find a Grave. July 13, 2012.

https://www.findagrave.com/memorial/93533021/robert-campbell-brinkley

Sherman, Janann. 2010. Dreamers, Thinkers, Doers: A Centennial History of the University of Memphis. Marceline. Walsworth Publishing Company.

Speer, William S. Repr. 2003. Sketches of Prominent Tennesseans: Containing Biographies and

Records of Many of the Families have Attained Prominence in Tennessee. Baltimore. Genealogical Publishing Company.

Solomon, Barbara Miller. 1985. In the Company of Educated Women: A History of Women and 
Higher Education in America. New Haven. Yale University Press.

"State Female College." 1870. Memphis Daily Appeal. February 7, 1871.

"State Items." 1871. Knoxville Daily Chronicle. March 7, 1871.

"The Brinkley Female College Ghost Story, Complete." 1871. Memphis Public Ledger. May 6, 1871.

"The Ghost." 1871. Memphis Daily Appeal. March 29, 1871.

"The Great Propensity of Mankind to be Gulled, Duped and Humbugged." 1871. Memphis Daily Appeal. March 22, 1871.

"The Latest Ghost Story." 1871. The Louisiana Democrat. April 18, 1871.

"The Spiritualist." 1871. Memphis Daily Appeal. October 19, 1871.

"To the Citizens of Memphis." 1881. Memphis Daily Appeal. April 7, 1881.

Tucker, Elizabeth. 2007. Haunted Halls: Ghostlore of American College Campuses. Jackson.

University Press of Mississippi.

"Uproar in a Tennessee Educational Institute." 1871. The Elk County Advocate. March 30, 1871. Watson, Samuel. 1872. The Clock Struck One and Christian Spiritualist: Being a Synopsis of the Investigations of Spirit Intercourse by an Episcopal Bishop, Three Ministers, Five Doctors, and Others, at Memphis, Tenn., in 1855; Also, the Opinion of Many Eminent Divines, Living and Dead on the Subject, and Communication Received from a Number of Persons Recently. New York. Samuel R. Wells.

Weisberg, Barbara. 2005. Talking to the Dead: Kate and Maggie Fox and the Rise of Spiritualism. San Francisco. HarperCollins books.

"Why the Hostility to Colonel Haynes?" 1872. Memphis Daily Appeal. August 12, 1872.

"Winston Jones Davie." 1887. Yale Obituary Record, 1859-1924. Yale University Library, Manuscripts and Archives, New Haven, Connecticut.

Young, John Preston. 1912. Standard History of Memphis, Tennessee, From a Study of Original Sources. Knoxville. H. W. Crew.

Yuko, Elizabeth. "8 Famous Figures Who Believed in Communicating with the Dead." History Stories. History. October 5, 2021. https://www.history.com/news/spiritualismcommunication-dead-figures. 